\title{
THE 2007 INTERNATIONAL CONVENTION AGAINST ENFORCED DISAPPEARANCE : SOME REFLECTIONS
}

\author{
Khushal Vibhute*
}

\section{Introduction}

Dignity and humanity of a human being lie at the heart of almost all the human rights instruments. In fact, they constitute the core values of human rights on which the whole edifice of the human rights jurisprudence is premised. The UN Charter, inter alia, affirms its faith in the dignity ${ }^{1}$ and the Universal Declaration of Human Rights (UDHR) proclaims that 'inherent dignity', along with 'equal and inalienable rights', of human beings is 'the foundation of freedom and justice in the world'. ${ }^{2}$ However, instances of denial of dignity to human beings by State agents and instrumentalities with impunity, on one or the other lame excuse, are frequently heard.

Enforced or involuntary disappearance which has its roots in the Nacht und Nebel ('Night and Fog') decree issued on December 7, 1941 by the German Fuhrer and Supreme Commander of the Armed Forces, Adolph Hitler, ${ }^{3}$ has now become worldwide. ${ }^{4}$ It is one of the most atrocious violations of human dignity of those who have been 'forced' to 'disappear'. It also constitutes 'an arbitrary deprivation of freedom' and causes 'serious danger to the personal

* Professor of Law, Addis Ababa University (AAU), Addis Ababa (Ethiopia)

${ }^{1}$ Preamble to the UN Charter.

${ }^{2}$ See, Preambulary paras 1 \& 10, UDHR.

3 The Decree provided that 'efficient and enduring intimidation can only be achieved either by capital punishment or by measures by which relatives of the criminal and population do not know the fate of the criminal'. Approximately 7,000 persons were secretly arrested, transferred to Germany and executed under the Decree. See, Trials of War Criminals before the Nuremberg Military Tribunal under Control Council Law No
10: Nuremberg, October 1946-April 1949 (1951), pp 75-76.

${ }^{4}$ For worldwide practice of enforced disappearance at a glance see, Tullio Scovazzi and Gabriella Citroni, The Struggle against Enforced Disappearance and the 2007 United Nations Convention, (Martinus Nijhoff, Leiden, 2007), pp 2 \& 14-72, 62, and Kirsten Anderson, How Effective is the International Convention for the Protection of All Persons from Enforced Disappearance Likely to be in Holding Individuals Criminally Responsible for Acts of Enforced Disappearance?, 7(2) Melbourne Jr of Int'l L 245 (2006). 
integrity, safety and life of the victim'. It denies him the right to liberty (even in some cases the right to life), the right not to be subjected to torture or inhuman treatment, the right to association (with his dear ones), and 'the right to a fair trial, to protection against arbitrary arrest, and to due process'. 5

It also denies his family members to associate with him. A prolonged isolation and deprivation of communication are in themselves cruel and inhuman to, and harmful to the psychological and moral integrity of, both-the disappeared and his relatives. His family members, relatives as well as dear ones, for obvious reasons, are subjected to an 'anguished uncertainty' ${ }^{6}$ and anxiety to know his whereabouts. They live in a situation of extreme insecurity, anguish and stress, torn between hope and despair. A systematic widespread enforced disappearance creates a situation of insecurity, fear and terror. ${ }^{7}$ It has 'devastating effects on the societies' in which it is practiced. ${ }^{8}$

Since more than two decades, the international community is engaged in combating the practice of involuntary or enforced disappearance and thereby upholding dignity of its victims. The struggle has culminated in the adoption by the UN General Assembly on December 20, 2006 of the International Convention for the Protection of All Persons from Enforced Disappearance (hereinafter the 2007 Convention). On February 6, 2007, the Convention was opened for signature in Paris.

The present paper endeavors to take a review, in brief, of the struggle of the United Nations against involuntary or enforced disappearance and to, in this backdrop, highlight some structural peculiarities of the 2007 Convention and of the institutional mechanism designed thereunder for preventing enforced disappearance.

Before dealing with the 2007 Convention, however, it is necessary to have an

\footnotetext{
${ }^{5}$ Inter-American Commission on Human ${ }^{7}$ Velasquez Rodriguez v Honduras, InterRights, Report on the Human Rights American Court of Human Rights, 1988, Situation in Chile, OEA/Ser.L/V/II.40 Ser. C No. 4, 9 Hum. Rts. L.J. 212 (1988), doc.10, of February 11, 1977.

${ }^{6}$ See, UN Doc E/CN.4/1990/13, para 339. Also see, Annual Report of the InterAmerican Commission on Human Rights 1978, OEA/Ser.L/II.47, doc $13 \mathrm{rev} 1$, of 29 June 1979, p 23 and Annual Report of the Inter-American Commission on $\mathrm{Hu}$ man Rights, 1980 - 1981, OEA/Ser. G, CP/doc 1201/1981, of 20 October 1981, p. 113. para 50. For extracts from the judgment, see, Henry J Steiner \& Philip Alston, International Human Rights in Context-Law, Politics, Morals (Oxford, 2000) 881-887. Also see, judgments of the Inter-American Court of Human Rights in: Godínez Cruz (delivered on 20 January 1989, para 163); Fairén Garbi and Solís Corrales (decided on 15 March 1989, para 147), and Blake (pronounced: 24 January 1998, para 65). ${ }^{8}$ UN Doc E/CN.4/1985/15, para 291.
} 
overview of the UN Declaration for the Protection of All Persons from Enforced Disappearance of 1992 (hereinafter the 1992 Declaration), the thitherto sole international instrument dealing exclusively with 'enforced disappearance'. An overview of the normative characters of 'enforced disappearance' reflected in the Declaration helps us in appreciating the structural and institutional paradigm of the 2007 Convention in a better way.

\section{Declaration on the Protection of All Persons from Enforced Disappearance (1992) - An Overview}

Showing its 'deep concern' for the then persistent enforced disappearance in many countries by 'officials of different branches or levels of Government' or by 'organized groups or private individuals acting on behalf of, or with support, direct or indirect, consent or acquiescence of the Government', considering it a 'crime against humanity', , and expressing the need to 'devise an instrument which characterize all acts of enforced disappearance of persons as very serious offences and sets forth standards designed to punish and prevent their commission', the UN General Assembly on December 18, 1992 adopted, without vote, the 1992 Declaration. ${ }^{10}$ The Declaration, proclaims a 'body of principles' (pertaining to enforced disappearance) and 'urges' all States to 'respect' them.

Art 1 of the Declaration perceives 'any act of enforced disappearance' as 'an offence to human dignity' and lists, in a non-exhaustive way, the human rights that are violated by acts of enforced disappearance. It says:

(1) Any act of enforced disappearance is an offence to human dignity. It is condemned as a denial of the purposes of the Charter of the United Nations and as a grave and flagrant violation of the human rights and fundamental free-

\footnotetext{
9 Subsequently, the Rome Statute for the Establishment of an International Criminal Court of 1998 has included 'enforced disappearance of persons' among the crimes against humanity 'when committed as part of a widespread or systematic attack directed against any civilian population, with knowledge of the attack'. [vide art 7(1)(i)]

${ }^{10}$ UN GA Resolution 47/133 of 18 December 1992. Prior to the resolution, the UN General Assembly, in its Resolution No. 33/173 of 18 December 1978 entitled 'Disappeared Persons', expressed its 'deep concern' over the 'disappearance of persons as a result of excesses on the
}

part of law enforcement and security authorities' and requested the Commission on Human Rights to consider the issue and to make appropriate recommendations. See, UN Doc A/ RES/33/173, 20 December 1978, para 158. For historical background of the Declaration see, W Tayler, Background to the Elaboration of the Draft International Convention on the Protection of All Persons from Enforced Disappearance, Review of the International Commission of Jurists (Special Issue on 'Impunity, Crimes Against Humanity and Forced Disappearance’) 2001, 63 et seq. 
doms proclaimed in the Universal Declaration of Human Rights and reaffirmed and developed in international instruments in this field.

(2) Any act of enforced disappearance places the persons subjected thereto outside the protection of the law and inflicts severe suffering on them and their families. It constitutes a violation of the rules of international law guaranteeing, inter alia, the right to recognition as a person before the law, the right to liberty and security of the person and the right not to be subjected to torture and other cruel, inhuman or degrading treatment or punishment. It also violates or constitutes a grave threat to the right to life.

The Declaration requires a State, as its primary obligation, inter alia, to: (i) not practice, permit or tolerate enforced disappearances [art 2(1)], (ii) contribute, by all means, to the prevention and eradication of enforced disappearances at national, regional and international level [art 2(2)], (iii) take effective legislative, administrative, judicial or other measures to prevent and terminate acts of enforced disappearance in territory under its jurisdiction [art 3], (iv) make all acts of enforced disappearance as offences under its criminal law and subject them, depending upon their gravity, to appropriate punishment [art 4(1)], (v) make perpetrators of enforced disappearance, including the State authorities and officials, also liable under civil law [Art 5], (vi) confer a right on a person having knowledge of, or legitimate interest in, enforced disappearance to complain to a competent and independent State authority and to seek prompt and impartial investigation of his complaint [art 13 (1)], and (vii) provide for prompt and effective judicial remedy and guarantees to the relatives of disappeared persons [arts $9 \& 13$ ].

Further, it precludes a State and its agents from justifying 'enforced disappearance' on any ground whatsoever, including a threat of war, a state of war, internal political instability or any other public emergency. ${ }^{11}$ It also expressly provides that 'no order or instruction of any public authority, civilian, military or other, may be invoked to justify an enforced disappearance' and that 'any person receiving such an order or instruction' has the 'right and duty not to obey it'. It requires a State to 'prohibit' 'orders or instructions directing, authorizing or encouraging any enforced disappearance'. ${ }^{12}$

Theoretically, the 1992 Declaration, being a resolution of the UN General Assembly, is not binding by itself. However, obligations of States indicated in the Declaration, in due course of time, have not merely remained as sym-

${ }^{11}$ Art 7.

12 Art 6.

${ }^{13}$ The Working Group was established in 1980 by the Commission on Human Rights by its Resolution 20 (XXXVI) of
29 February 1980. The UN General Assembly, through its Resolution 35/193 of 15 December 1980, endorsed its creation. It is composed of five independent experts. 
bolic obligations. The UN Working Group on Enforced or Involuntary Disappearances (hereinafter the WGEID), ${ }^{13}$ since 1993, started reporting annually on the implementation of the Declaration and obstacles encountered therein. It has frequently invited relatives of disappeared persons, organizations representing them, and human rights NGOs to periodically inform and update it about the steps undertaken by Governments for implementing the Declaration. It regularly transmits to the Governments concerned a summary of allegations of enforced disappearance and of obstacles encountered in the implementation of the Declaration received from relatives of disappeared persons and NGOs. It invites the concerned states to, if they wish, comment upon the allegations of enforced disappearance leveled against them.

In its annual reports, the WGEID has stressed that States are obliged to implement the Declaration. According to the WGEID, this obligation is not merely restricted to the States where acts of involuntary disappearances have occurred in the past or continue to occur. All other States are also obliged to undertake appropriate legislative and other preventive measures to ensure that acts of enforced disappearance do not occur in future. ${ }^{14}$ In its General Comment on Article 3 of the Declaration, requiring States 'to take effective legislative, administrative, judicial and other measures to prevent and terminate acts of enforced disappearance', the WGEID emphasized:

The provision calls for action both by States in any territory under their jurisdiction of which acts of enforced disappearance might have occurred in the past and by States in which such acts have not occurred. All States must have appropriate machinery for preventing and terminating such acts and are therefore under an obligation to adopt the necessary measures to establish such machinery if they do not have it. ... The provision must be understood as the general framework for guiding States and encouraging them to adopt a set of measures. It must be understood that the international responsibility of States in this regard arises not only when acts of enforced disappearance occur, but also when there is a lack of appropriate action to prevent or terminate such acts. Such responsibility derives not only from omissions or acts by the government and the authorities and officials subordinate to it, but also from all the other government functions and mechanism, such as the legislature and the judiciary, whose acts or omissions may affect the implementation of this provision. ${ }^{15}$

${ }^{14}$ Office of the High Commissioner for Human Rights, United Nations Working Group on Enforced and Involuntary Disappearances, Fact Sheet No 6 (Rev. 2), Enforced or Involuntary Disappearances (2006).

15 See, United Nations Working Group on
Enforced or Involuntary Disappearances, Annual Report for 2005, E/ CN.4/2006/56, 27 December 2005. The Working Group has also adopted General Comments on the implementation of other articles dealing with States' obligations under the Declaration. 
However, in spite of sincere efforts made by (and frequent reminders of) the WGEID, the Declaration has not been ostensibly effective in combating the practice of enforced disappearance. ${ }^{16}$

\section{The Background towards the 2007Convention}

Despite the UN General Assembly's Resolutions ${ }^{17}$ condemning enforced disappearance and the 1992 Declaration, enforced disappearances, as stated above, have remained unabated. Moreover, measures in international law for holding individuals criminally responsible for acts of enforced disappearance have been limited.

The failure of the international community to put an end to the ongoing practice of enforced disappearance throughout the world was attributed, inter alia, to the lack of universally binding legal instrument against enforced disappearances and of a sound legal framework for the protection of persons from enforced disappearances and for handling perpetrators thereof. In 2001 the Commission on Human Rights, with a view to identifying these 'gaps', appointed Manfred Nowak, an independent expert, 'to examine existing international criminal and human rights framework for the protection of persons from enforced or involuntary disappearance' and 'to report' to it and to WGEID. ${ }^{18}$ In 2002, Manfred Nowak, briefing the Commission on Human Rights, observed:

There do exist plenty of gaps and ambiguities in the present legal framework which clearly underscore the urgent need for a binding universal instrument in order to prevent the widespread practice of enforced disappearances, one of the most serious human rights violations which is directed at the core of the dignity of both the disappeared person and his family. ... The most important gap is the lack of binding obligation to make sure that enforced disappearance is a crime under domestic law with appropriate penalties, and that the principle of universal jurisdiction applies to the crime. It is important to note that Article 7 of the Rome Statute of the International Criminal Court (ICC) recognizes enforced disappearance as a crime against humanity but perpetrators will only in very exceptional circumstances of a widespread and systematic practice be held accountable before the ICC.

\footnotetext{
${ }^{16}$ Eight years after adoption of the Declaration, the UN General Assembly had to record its 'deep concern' for 'the intensification of enforced disappearances in various regions of the world' and for 'the growing number of reports concerning the harassment, ill-treatment and intimidation of witnesses of disappearances or relatives of persons who have disap-

peared'. See, UN GA Resolution 55/103 adopted at its fifty-fifth session (2000).

17 See, UN GA Resolution 33/173 of 18 December 1978, Resolution 49/193 of 23 December 1994, Resolution 51/94 of 12 December 1996, and Resolution 53/150 of 9 December 1998.

${ }^{18}$ UN Commission on Human Rights, Resolution 2001/46, 23 April 2001
} 
Effective domestic criminal justice must, therefore, be regarded as the most important mechanism in order to deter and prevent disappearances. ${ }^{19}$

At another forum Manfred Nowak also stressed:

Although there seems to be general agreement that enforced disappearances need to be combated by relevant measures under domestic criminal law (including the principle of universal jurisdiction) and by a broad variety of preventive measures, no legally binding universal obligations exist in this respect. Since the protection of international criminal law will only apply in exceptional cases, universal jurisdiction in clearly defined individual cases of enforced disappearance, with appropriate punishment, will constitute the most effective measure to deter the practice of enforced disappearance in the future. ${ }^{20}$

In the absence of a universally legally binding instrument against enforced disappearance and the increased instances of involuntary disappearance across the world, it was felt necessary by the international community to have a universally legally binding instrument on enforced disappearance. Ultimately, such a universal legal binding instrument against enforced disappearance emerged in the form of the International Convention for the Protection of All Persons from Enforced Disappearance of 2007.

It is indeed interesting to note that the Convention, in the present form, is an outcome of a quarter a century's struggle against enforced disappearance. The first effort to promote an international instrument against enforced disappearance was undertaken in 1981 by the Human Rights Institute of the Paris Bar Association, when it arranged a colloquium on the issue of enforced disappearance. Following the colloquium, the Latin American Federation of Associations for Relatives of the Detained-Disappeared adopted a draft convention in its annual congress held in 1982 in Peru. In 1986, a draft Declaration was adopted in the First Colloquium on Forced Disappearances held in Colombia and convened by the NGO Jose Alvear Restrepo Lawyers Collective of Bogotá, which was transmitted to the UN Working Group on Enforced Disappearance and to the Commission on Human Rights urging them to take initiatives for international convention on enforced disappearance. ${ }^{21}$

\footnotetext{
${ }^{19}$ United Nations High Commissioner for ${ }^{20}$ UN Commission on Human Rights, Human Rights, 26 March 2002, Oral Working Group January 2002 Report, Presentation of the Report submitted by Mr Manfred Nowak, Independent Expert, on the International Legal Framework for the Protection of Persons from Enforced Disappearance, Pursuant to Para 11 of Commission Resolution 2001/46. Civil and Political Rights, Including Questions of Disappearance and Summary Execution, UN ESCOR, $58^{\text {th }}$ Session, UN Doc E/CN.4/2002/71, 8 January 2002, para 96.

${ }^{21}$ See, ibid., para 43.
} 
In 1998, the Sub-Commission for the Protection of Human Rights, after four years of work and a series of consultative meetings with experts from the United Nations and NGOs, adopted the Draft International Convention for the Protection of All Persons from Enforced Disappearance. ${ }^{22}$ Subsequently, during 2001 the Commission on Human Rights, out of its deep concern to react to the increased practice of enforced disappearances decided, with the concurrence of the ECOSOC, to establish an Intersessional Open-ended Working Group to elaborate a 'draft legally binding normative instrument for the protection of all persons from enforced disappearance'. ${ }^{23}$

The Intersessional Open-ended Working Group based its work and subsequent discussions on the 1998 Draft Convention. After more than three years of debate, it concluded its work and adopted on September 23, 2005 the International Convention for the Protection of All Persons from Enforced Disappearance. ${ }^{24}$ Subsequently, on June 26, 2006, the newly established Human Rights Council adopted the draft Convention. ${ }^{25}$ Later on, the Third Committee of the UN General Assembly on November 13, 2006 adopted it. ${ }^{26}$ Finally, on December 20, 2006 the UN General Assembly, in its $82^{\text {nd }}$ plenary meeting, adopted the Convention. On February 6, 2007, the Convention was opened for signature ${ }^{27}$ and was signed by 57 states. $^{28}$

However, it is pertinent to note here that some experts and State representatives, during consultative meetings, questioned propriety of the Convention itself as a universally legal binding instrument on enforced disappearances. ${ }^{29}$ Delegations of the States participating in the deliberations took two divergent

22 United Nations, Economic and Social Council, E/CN.4/Sub.2/1998/19, Annex, 19 August 1998. For further comments and analysis of the Draft Convention see, Federico Andreu Guzman, the Draft International Convention on the Protection of All Persons from Forced Disappearance, Review of International Commission of Jurists (Special Issue on 'Impunity, Crimes Against Humanity and Forced Disappearance') 2001, 73 et seq. For historical background see, W Tayler, Background to the Elaboration of the Draft International Convention on the Protection of All Persons from Enforced Disappearance, supra n 10.

23 Resolution No. 2001/46 (para 12) of 23 April 2001 and Resolution No. 2002/41 (para 13) of 23 April 2002.
${ }^{24}$ United Nations, Economic and Social Council, Report of the Intersessional Open-ended Working Group to Elaborate a Draft Legally Binding Normative Instrument for the Protection of All Persons from Enforced Disappearances, UN Doc E/CN.4/2006/57, 2 February 2006.

25 United Nations, Human Rights Council, Summary Records of the $3^{\text {rd }}$ Meeting, A/ HRC/2/SR.3,3 October 2006. Resolution $1 / 1$.

${ }^{26}$ United Nations, Human Rights Council, Report of the Human Rights Council to the Third Committee of the General Assembly, A/C.3/61/L.17, 27 October 2006; and GA/SHC/3872.

${ }^{27}$ Resolution 61/177 of 20 December 2006. 
standpoints. Delegations from Latin American States, Italy and Spain, believing that the then existing international human rights instruments are inadequate to combat the practice of enforced disappearance, favored a separate convention on enforced disappearance with a new monitoring mechanism. They apprehended that entrusting the Human Rights Committee, which is already over-burdened, with an additional responsibility of preventing enforced disappearance would be 'counter-productive to the human rights system as a whole'. They stressed that a separate treaty on enforced disappearance with a new monitoring body would send 'a strong message' to victims of enforced disappearance and their families.

On the other hand, delegations of Canada, the USA, Germany, Russia, China, Egypt, and Iran, believing that the then existing international human rights instruments and the Human Rights Committee are adequate to stall the practice of involuntary disappearance, pleaded for an optional protocol to the ICCPR (in lieu of an autonomous instrument on enforced disappearance). Formulating a new legal instrument and creating another monitoring body for preventing enforced disappearance, in their opinion, would make 'no sense'. ${ }^{30}$ The Canadian delegation, for example, responding to the Draft Convention on Enforced Disappearance and commenting on its necessity, felt that the proposed Convention was unwarranted as the existing legal instru-

28 The 57 States which, on February 6, 2007, signed the Convention and thereby expressed their commitment to combat enforced disappearance, were: France, Albania, Algeria, Argentina, Austria, Brazil, Burkina Faso, Burundi, Congo, Croatia, Ghana, Guatemala, Haiti, Japan, Lithuania, the Maldives, Moldavia, Morocco, Uganda, Senegal, Serbia, Sierra Leone, the FYROM, Chad, Tunisia, Vanuatu, Belgium, Bolivia, BosniaHerzegovina, Cameroon, Cape Verde, Chile, Comoros, Costa Rica, Cuba, Cyprus, Finland, Grenada, Honduras, India, Kenya, Lebanon, Luxembourg, Madagascar, Malta, Mexico, Monaco, Mongolia, Montenegro, Niger, Paraguay, Portugal, Samoa, Sweden, Uruguay, Mali, Azerbaijan. So far (as of July 2008) 73 states have signed the Convention. Hitherto, only 4 states, namely, Albania, Argentina, Honduras and Mexico have ratified the Convention. On January 3, 2008, the Lower House of Parliament of Chile has approved the Convention. On July 8, 2008, the French Senate has ratified the Convention. The President has yet to accord the executive fiat to make the ratification final.

29 See United Nations, Commission on $\mathrm{Hu}-$ man Rights, Question of Enforced or Involuntary Disappearances, E/ CN.4/2001/69/Add.1, 14 March 2001.

30 See, United Nations, Economic and Social Council, Intersessional Open-ended Working Group to Elaborate a Draft Legally Binding Normative Instrument for the Protection of All Persons from Enforced Disappearance, $5^{\text {th }}$ Session (Geneva, 12-23 September 2005). For a comparative account of these suggested alternatives see, UN Commission on $\mathrm{Hu}-$ man Rights, Working Group January 2002 Report, Civil and Political Rights, Including Questions of Disappearance and Summary Execution, UN ESCOR, $58^{\text {th }}$ Session, supra $n$ 20, paras 99-102. 
ments, like the 1992 Declaration, the ICCPR, the UN Convention against Torture, and the 1998 Rome Statute, provide 'sufficient protection against enforced disappearance'. It further asserted that the implementation mechanism (in the form of Committee against Enforced Disappearance) proposed under the Convention would unnecessarily add to the existing 'proliferation of treaty monitoring bodies and international instruments' and to 'the States' reporting burdens'. ${ }^{31}$

The delegation of Switzerland took a different line of argument and pleaded for a Third Optional Protocol to the ICCPR, in lieu of the proposed Convention on Enforced Disappearance. Giving preference to the existing Human Rights Committee over the proposed Committee against Enforced Disappearance, it observed: ${ }^{32}$

The question now is whether ... the 1992 Declaration gives a strong enough political signal to the international community to put an end to enforced disappearance throughout the world. The answer is that it does not. ...

The International Covenant on Civil and Political Rights (Articles 6, 7, 9, $10,14,16$ and 26) covers virtually all the rights violated by a forced disappearance. It would thus be appropriate to consider whether, instead of a completely new convention, a third protocol could be added to the Covenant to deal with forced disappearance. Such a Protocol would contain substantive provisions inspired by the draft convention, namely a comprehensive, specific definition of forced disappearances, making it a criminal offence, and obligations to prevent, investigate and punish such disappear-

31 See, United Nations, Commission on Human Rights, Question of Enforced or Involuntary Disappearances, supra $\mathrm{n}$ 29, 'Comments by Canada'.

${ }^{32}$ United Nations, Commission on Human Rights, Question of Enforced or Involuntary Disappearances, ibid, 'Comments by Switzerland'. In October 2004, the Chairman of the Human Rights Committee, while participating in a session of the Intersessional Openended Working Group, also pleaded for an Optional Protocol to the ICCPR with entrusting the task of combating enforced disappearance to the Human Rights Committee, which, according to him, has a many years' of experience of handling human rights. The proposed move, he asserted, would ensure the continuity and consistency of the $\mathrm{Hu}-$ man Rights Committee's jurisprudence.
Increasing number of monitoring mechanism, he opined, could lead to problems with consistency of jurisprudence. The proposal was greeted with mixed responses. Some participating delegations supported the proposal. While other delegations failed to see any merit in the proposal as it, inter alia, would entail modifications in the terms of reference of the Human Rights Committee and consequential apt amendments to the Covenant. See, UN Doc E/ CN.4/WG.22/CRP.6, 9 February 2005, pp 12-15. Also see, UN Commission on Human Rights, Report of the Intersessional Open-ended Working Group to Elaborate a Draft Legally Binding Normative Instrument for the Protection of All Persons from Enforced Disappearance, UN Doc E/CN.4/2005/66, 10 March 2005. 
ances, to cooperate internationally and to offer reparation, this operation would avoid the setting up of a new, costly mechanism to monitor the States Parties: the Human Rights Committee would be in charge of it.

However, in the backdrop of the escalating and widespread instances of enforced or involuntary disappearance in spite of decades' existence of the referred to international instruments, it, in the present submission, becomes difficult to appreciate the proposals mooted by Canada and Switzerland. Obviously, international human rights instruments in vogue and the monitoring mechanism designed thereunder have not indeed been able to desist, rather deter, States from the practice of enforced disappearance.

In fact, the international mobilization, initiated a quarter-century ago, for a separate comprehensive international instrument on enforced disappearance stands as the testimony of the inadequacy of these international instruments and the legal framework designed thereunder in combating acts of involuntary disappearances. The existence of these international instruments and falling back thereon, therefore, hardly justify the stand taken by Canada and Switzerland. The proliferation of international instruments and monitoring bodies adding to States' reporting burdens, apprehended by Canada, hardly appeals when one recalls the increasing number of disappearances in the world. States' reporting burden cannot be, for obvious reasons, considered to be worse than the practice of enforced disappearance and its consequences.

Contrary to the assertion of Canada, the 1992 Declaration, the ICCPR, and the Convention against Torture, as witnessed in the past, have failed to either give States and their agents a strong signal to prevent and suppress the practice of enforced disappearance or make them sensitive to the innumerable untold miseries and sufferings of disappeared persons and of their relatives. The 1992 Declaration, in spite of efforts made by the WGEID, as stated above, has not been able to eradicate the practice of enforced disappearance. The Convention against Torture, due to some inbuilt structural as well as operational weaknesses, has also not been able to combat torture of disappeared persons to the expected level. The 1998 Rome Statute, by virtue of its Article 7 , comes into play only when an act of enforced disappearance is 'committed as a part of a widespread or systematic attack directed against any civilian population'.

Furthermore, the Statute does not create any obligation pertaining to prevention, investigation and suppression of enforced disappearance under the perspective of international human rights law. In fact, it does not go beyond the arena of international criminal law. The ICCPR, undoubtedly, protects the most of the rights violated by an enforced disappearance. However, the 
Covenant does not establish specific obligations with regard to prevention, investigation, repression and international cooperation in cases of enforced disappearances. It also does not stipulate any obligation to codify enforced disappearance as an autonomous offence under domestic criminal law, to exercise territorial and extra-territorial criminal jurisdiction with respect to the perpetrators of the offence, and to maintain registers of detained persons. Further, one should not overlook the fact that there in international human rights law exist a couple of comprehensive international instruments dealing with the rights incorporated in, and protected under, the UDHR and ICCPR. ${ }^{33}$

Nevertheless, the delegates, after negotiations, agreed to have a separate convention on enforced disappearance and a new monitoring body in the form of Committee on Enforced Disappearance for combating the practice of involuntary disappearance.

\section{Normative and Institutional Framework of the 2007 Convention}

Recalling that the extreme seriousness of enforced disappearance constitutes a crime against humanity, expressing its determination 'to prevent' enforced disappearance and to 'combat impunity' therefor, and affirming the 'right of any victim to know the truth about the circumstances of an enforced disappearance and the fate of disappeared person, and the right to freely seek, receive and impart information', the 2007 Convention, inter alia, defines 'enforced disappearance', imposes a set of obligations on the States Parties and provides for the establishment of mechanism for its implementation.

The Convention has three Parts. Part I defines 'enforced disappearance' and sets out the main requirements that need to be addressed in the domestic law of acceding States. Part II deals with the establishment of a Committee on Enforced Disappearances, the institution charged with the responsibility of monitoring 'enforced disappearance' in the States Parties and of implementing the Convention, while Part III provides for formalities required for ratification or accession and entry into force of the Convention.

\subsection{Enforced disappearance: Normative contours and nature}

The 2007 Convention not only denounces the act of enforced disappearance but also precludes a State from justifying it on any ground whatsoever. Art 1 proclaims:

${ }^{33}$ For example, see the International Convention on the Elimination of All Forms of Racial Discrimination (1965), the Convention on the Elimination of All Forms of Discrimination against Women

(1979), and the Convention on the Rights of Child (1989). See, Tullio Scovazzi and Gabriella Citroni, The Struggle against Enforced Disappearance and the 2007 United Nations Convention, supra n 4. 
1) No one shall be subjected to enforced disappearance.

2) No exceptional circumstances whatsoever, whether a state of war or a threat of war, internal political instability or any other public emergency, may be invoked as a justification for enforced disappearance.

Art 1(1) explicitly prohibits per se acts of enforced disappearance and holds individuals criminally responsible therefor. In fact, it creates a human right against enforced disappearance. And art 1(2), which is ostensibly premised on a similar provision contained in the 1992 Declaration, extends the application of the prohibition on enforced disappearance to all situations and contexts, including during domestic or international armed conflict, other internal tensions, and in times of peace. It prohibits any justification for acts of enforced disappearance.

Article 2 defines 'enforced disappearance' as:

For the purposes of this Convention, 'enforced disappearance' is considered to be the arrest, detention, abduction or any other form of deprivation of liberty by agents of the State or by persons or groups of persons acting with the authorization, support or acquiescence of the State, followed by a refusal to acknowledge the deprivation of liberty or by concealment of the fate or whereabouts of the disappeared person, which places such a person outside the protection of law.

A plain reading of the definition of 'enforced disappearance' reveals that 'enforced disappearance' per se is not conceptually linked with 'crime against humanity', even though it is asserted in its Preamble, ${ }^{34}$ and the Rome Statute, which explicitly perceives 'enforced disappearance', when committed as a part of a widespread or systematic attack directed against any civilian population, with knowledge of the attack, as a crime against humanity. ${ }^{35}$

It is important to recall here that the deliberations at the 1981 Paris Colloquium and the 1986 Bogotá Colloquium, and the Convention drafted and adopted in 1982 by the Latin American Federation of Associations for Relatives of the Detained-Disappeared, perceived 'enforced disappearance' as a 'crime against humanity'. The 1998 Draft Convention on Enforced Disappearance also explicitly referred to 'enforced disappearance' as a 'crime against humanity' in its Preamble as well as in its provisions [Arts 3 \& 15 (1)].

In spite of such references in the documents that preceded the 2007 Convention and the efforts that influenced its structural framework, the linkage between enforced disappearance and crime against humanity was dropped from the final version of the 2007 Convention due to concerns voiced by a number

\footnotetext{
${ }^{34}$ See, Preambulary para $5 . \quad \quad \quad{ }^{35}$ Art 7(1) (i).
} 
of States during meetings of Intersessional Open-ended Working Group that drafted the 2007 Convention. In fact, the proposal by many of the Latin American and European countries, and of NGOs for making the notion of crime against humanity explicit in Article 2 of the Convention was greeted with resistance by other states. With a view to keeping the contextual reference to enforced disappearance as a crime against humanity in the Rome Statute intact in the 2007 Convention, they opposed any specific reference in the operative part of the Convention to enforced disappearance as a crime against humanity. Final text of the 2007 Convention, as an outcome of the conflicting stands taken by the states, merely makes generic mention of 'enforced disappearance' as 'a crime against humanity' in its Preamble and in Article $5 .^{36}$

Article 5 says that 'the widespread practice of enforced disappearance constitutes a crime against humanity as defined in applicable international law and shall attract the consequences provided for under such applicable international law'. A reading of Article 5, in the backdrop of Article 1(1) of the Convention, makes it clear that the Convention maintains a distinction between per se acts of enforced disappearance and 'the widespread or systematic practice of enforced disappearance' amounting to a 'crime against humanity'. The purpose of Article 5, therefore, appears to merely affirm the existing customary international law and Article 7(1) (i) of the 1998 Rome Statute. ${ }^{37}$ It cannot be perceived as an obligatory provision that requires States Parties to criminalize enforced disappearance as a crime against humanity in their domestic penal laws. ${ }^{38}$

However, in the light of the purpose and ambit of the Rome Statute and of the 2007 Convention, the reluctance to make specific reference to enforced dis-

${ }^{36}$ However, throughout the drafting of the Convention, some delegations expressed their concern over the inclusion and wording of art 5. The US delegation proposed its deletion from the main text of the Convention and urged to place it in Preamble to the Convention, as it (art 5) was not operative and could be interpreted as imposing a requirement on States to criminalize enforced disappearance as a crime against humanity in domestic penal laws. While other delegations expressed their apprehension that art 5 could weaken existing international law, as it did not correspond to the 'definition' of crime against human- ity in international law. See, United Nations, Economic and Social Council, Report of the Intersessional Open-ended Working Group to Elaborate a Draft Legally Binding Normative Instrument for the Protection of All Persons from Enforced Disappearances, supra n 24.

${ }^{37}$ However, it is argued that art 5 is applicable to 'situations' that fall within the 1998 Rome Statute as well as to other cases of enforced disappearance. See, Susan McCrory, the International Convention for the Protection of all Persons from Enforced Disappearance, 7 Human Rights L Rev 545 (2007).

38 See, supra n 24, para 106. 
appearance as a crime against humanity in the definitional clause of the Convention does not seem sound. The former Statute is primarily concerned with competence of the ICC to try and punish the offence of 'widespread and systematic' enforced disappearance, while the latter Convention is designed to combat the practice of enforced disappearance and to protect victims thereof. It, therefore, needs to address to different contours of enforced disappearance.

Moreover, it is pertinent to note here that the linkage between 'enforced disappearance' and 'crime against humanity' is not of mere semantic importance but is of some significant legal consequences. A perpetrator of an act of enforced disappearance that amounts to a crime against humanity, unlike a perpetrator of an isolated act of enforced disappearance, may be held criminally responsible at international human rights or international criminal law. Legal consequences that flow from classifying enforced disappearance as a crime against humanity are related, inter alia, with individual and State responsibility, universal jurisdiction, the obligation to extradite ${ }^{39}$ or try those responsible for the crime, the inapplicability of statutes of limitation, ${ }^{40}$ amnesties, pardons, and the obligation of States to cooperate at the international level in investigation and sanctioning of crime.

The definition of 'enforced disappearance', articulated in the Convention, excludes from its ambit acts enforced disappearance effected by non-State actors. But interestingly Article 3 puts an obligation on the States Parties 'to take appropriate measures to investigate' acts of enforced disappearances committed by non-State actors and 'to bring' them 'to justice'. An obvious legal consequence of Article 3 is that non-State actors cannot be held responsible under international law for their acts of enforced disappearance. However, in the light of provisions of Article 5 of the Convention, non-State actors can be held criminally responsible under international law if their acts of enforced disappearance amount to 'widespread or systematic practice of enforced disappearance’.

Recalling the numerous escalating incidences of enforced disappearance worldwide by guerrilla fighters, groups fighting the Government, and mem-

${ }^{39}$ Art 16 of the 2007 Convention permits a State Party not to extradite a person accused of enforced disappearance to another state when the person is 'in danger of being subjected to enforced disappearance' there.

${ }^{40}$ Interestingly, Article 8 of the 2007 Convention allows a State Party to apply a statute of limitation in respect of enforced disappearance, with a rider that the period of limitation should be of 'long duration', and proportionate to the extreme seriousness of the offence, and it should commence from the moment the offence of enforced disappearance ceases. 
bers of organized criminal gangs, and heinous nature of (even an isolated act of) enforced disappearance and its severe implications on the victim and his relatives, such a restriction [i.e. systematic practice of enforced disappearance] for imposing international criminal responsibility does not seem sound. There can hardly be two opinions about States' primary responsibility for acts of enforced disappearance by non-State actors and for protection of victims of involuntary disappearance. In this context, Article 3, indeed, takes the struggle against enforced disappearance a step backward.

At this juncture, some reflections can be made on the substantive aspects of the definition of 'enforced disappearance'. A reading of Artilce 2 of the Convention makes it clear that 'enforced disappearance', for the purposes of the Convention, has four limbs or components. They are: (i) deprivation of liberty (by arrest, detention, abduction, or any other form), (ii) by or with the support or acquiescence of a State agent, (iii) a refusal to acknowledge that deprivation of liberty, and (iv) concealment of the fate and whereabouts of the disappeared person that places him outside the protection of law. The first three components are precise in their formulations. Plausibly, they are derived from the similar definitional phrases found in the definition of 'enforced disappearance' embodied in the 1992 Declaration. However, the fourth limb of 'placement (of the victim) outside the protection of law', probably inspired by the definitional clause of the 1992 Declaration, brings ambiguity in the definition of enforced disappearance in the 2007 Convention.

The phrase used in Article 1 of the 1992 Declaration is contextually linked with consequence of 'enforced disappearance'. But the manner in which it is used and formulated in Artcle 2 of the 2007 Convention leaves scope for interpretation. It is not clear as to whether 'removal from the protection of the law' is an autonomous (fourth) element of the offence of 'enforced disappearance' or a simple consequence of the existence of an enforced disappearance. If it is treated as one of the elements of the offence of enforced disappearance, it will become obligatory on part of the States Parties to the Convention to put it, along with the first three, in their domestic criminal law. But if it is considered as a mere consequence of the deprivation of liberty, it would be left to their choice to put or not in the respective penal law.

During the negotiation processes of the 2007 Convention, both the views were expressed by delegations of the participating states. ${ }^{41}$ Some delegations, including of China, Egypt and the UK, expressed the view that 'placing a

${ }^{41}$ See, UN Commission on Human Rights, Report of the Intersessional Open-ended Working Group to Elaborate a Draft Legally Binding Normative Instrument for the Protection of All Persons from Enforced Disappearance, supra n 32, para 23. 
person outside the protection of the law' constituted a fourth element of the offence of enforced disappearance. ${ }^{42}$ And, some other delegations argued that the part of definition referring to 'placing a person outside the protection of the law' was simply a consequence of disappearance and not a part of the definition in its own right'. ${ }^{43}$ The Argentine delegation was more precise in putting forward its interpretation of the phrase. It stated that the phrase could not be construed as an additional element, as removal of a person from the protection of the law was inherent in an enforced disappearance, and a consequence resulting from the cumulative effect of the other three elements, namely deprivation of liberty, State responsibility and a refusal to acknowledge the whereabouts or fate of the 'disappeared person'. ${ }^{44}$

However, the UN Working Group decided to retain the phrase 'which place (s) such a person outside the protection of the law' in Article 2 of the 2007 Convention, noting that it will make for 'constructive ambiguity' ${ }^{45}$ as the national legislators will have the option of interpreting whether placing a person outside the protection of the law is an additional element or a consequence of the crime of enforced disappearance. ${ }^{46}$

\subsection{Major obligations of the States Parties}

The 2007 Convention, in pursuance of its determination to prevent enforced disappearances, to combat impunity of the perpetrators, and to render justice to the victims of enforced disappearance and their relatives, imposes set of obligations on the States Parties and requires them to undertake 'necessary measures'. These obligations are self-evident. A few prominent among them need to mention here.

A State Party will be obligated:

(i) to ensure that forced disappearance constitutes an offence under its criminal law and to make it punishable by appropriate punishment (corresponding to its gravity and mitigating as well as aggravating circumstances) [Arts 4 \& 7],

(ii) to hold a person who commits, orders, solicits or induces the commission of forced disappearance, assists or participates in the commission of an act of enforced disappearance, criminally responsible, and to disallow a subordinate officer to justify his act of enforced disappearance on the ground of 'superior orders' [Art 6],

(iii) to take necessary measures to establish its jurisdiction over the person accused of an enforced disappearance, when: (a) the offence is committed in its territory, (b) he happens to be its national, and (c) the disappeared

\begin{tabular}{l|l|l}
${ }^{42}$ See, supra $\mathrm{n} 24$, para 92. & ${ }^{44}$ See, ibid., para 91. \\
${ }^{43}$ Id. & ${ }^{46}$ See, See, ibid, para 92.
\end{tabular} 
person was its national [Art 9],

(iv) to extradite a person accused of an enforced disappearance or to surrender him (or her) to another State in accordance with its international obligations or to surrender him (or her) to appropriate international criminal tribunal, if not, submit the case to its competent authorities for prosecution [Art 11], ${ }^{47}$

(v) to carry out prompt and impartial investigation of an alleged enforced disappearance and to protect the complainant, witnesses, relatives of the disappeared person, their defence counsel, and persons participating in the investigation, against ill-treatment or intimidation as a consequence of the complaint or evidence given, [Art 12(1)],

(vi) to ensure that persons suspected of having committed the alleged enforced disappearance are not in a position to interfere with or influence the progress of the investigation [Art 12(4)],

(vii) to cooperate with each other in criminal proceedings relating to enforced disappearance, in assisting victims of enforced disappearance, and in locating and releasing disappeared persons [arts 14 \&15],

(viii) to maintain information about persons deprived of their liberty and to make it, as a matter of right, promptly available upon request [Arts 17-20],

(ix) to take appropriate measures to ensure that victims of enforced disappearance have the right to know the truth: (a) regarding the circumstances of the enforced disappearance, (b) the progress and results of the investigation, and (c) the fate of the disappeared person [Art 24(2)],

(x) to ensure, through appropriate law, that victims of enforced disappearance have the right to obtain reparation (including restitution, rehabilitation, restoration of dignity and reputation, and guarantees of non-repetition), and prompt, fair and adequate compensation [Art 24 (4) \& (5)], and

(xi) to take appropriate measures to search, locate and release disappeared persons, and, in the event of death, to locate, respect and return the human remains of the victims of enforced disappearance [art 24(3)].

\section{Monitoring and Implementation Schemes and Strategy}

The 2007 Convention provides for the establishment of a new, autonomous body, the Committee on Enforced Disappearance (CED), for monitoring the implementation of the Convention by the States Parties and protecting all persons from enforced disappearance. The CED will consist of ten independ-

\footnotetext{
${ }^{47}$ However, art 13 makes the offence of enforced disappearance as deemed an extraditable offence in the extradition treaty that exists between the States Parties before the Convention enters into force. In addition, the States Parties will have to undertake to include an act of enforced disappearance as an extraditable offence in any extradition treaty that they will conclude after they become parties to the Convention.
} 
ent and impartial experts of high moral character and of recognized competence in the field of human rights, elected by the States Parties to the Convention. $^{48}$

The CED will be empowered: (i) to receive, through the UN SecretaryGeneral, a State Report on the measures taken to give effect to its obligations under the Convention, and to consider it, ${ }^{49}$ (ii) to receive and consider individual communications from or on behalf of individuals claiming to be victims of enforced disappearances by a State Party that will make a declaration recognizing the competence of the CED for doing so, ${ }^{50}$ (iii) to receive and consider inter-State communications alleging that another State Party is not fulfilling its obligations under the Convention, provided both the States involved in the communication have, through declaration, recognized the competence of the CED to this effect, ${ }^{51}$ and (iv) to, after receiving reliable information indicating serious violations of the Convention, undertake field inquiries, through its member(s), to get immediate report about the enforced disappearance. ${ }^{52}$

In addition to these traditional quasi-judicial competences of the CED, the 2007 Convention, with a view to combating enforced disappearance effectively, has, unlike other treaties on human rights, devised two new innovative strategies. It empowers the CED: (i) to invoke a sort of 'urgent or emergency procedure' to seek and find disappeared persons, and (ii) to bring cases of 'exceptional gravity' to the attention of the UN General Assembly.

Article 30, which deals with the 'emergency procedure' for seeking and finding disappeared persons, runs as follows:

1. A request that a disappeared person should be sought and found may be

\footnotetext{
${ }^{48}$ Art 26 gives in detail the manner of election of the members of the CED. However, art 27, in the backdrop of the doubts expressed by a number of State delegations about propriety of the CED and suggestion that the monitoring function be entrusted to the Human Rights Committee, provides for the evaluation, within 4-6 years following the entry into force of the Convention, of the functioning of the CED by the Conference of States for deciding to transfer (or not) the monitoring function to another body. See, United Nations, General Assembly, Third Committee Approves Draft Resolu-

Disappearance, GA/SHC/3872, 13 November 2006. ${ }^{49}$ Art 29.

${ }^{50}$ Art 31. It was emphasized that art 31(1) allows NGOs to bring cases before the CED on behalf of alleged victims of enforced disappearance. See, United Nations, Economic and Social Council, Report of the Intersessional Open-ended Working Group to Elaborate a Draft Legally Binding Normative Instrument for the Protection of All Persons from Enforced Disappearances, supra n 24, para 53. tion Concerning Convention on Enforced ${ }^{52}$ Art 33.
} 
submitted to the Committee, as a matter of urgency, by relatives of the disappeared person or their legal representatives, their counsel or any person authorized by them, as well as by any other person having legitimate interest.

2. If the Committee considers that a request for urgent action submitted in pursuance of Paragraph 1 of this Article:

(a) Is not manifestly unfounded;

(b) Does not constitute an abuse of the right of admission of such requests;

(c) Has already been duly presented to the competent bodies of the State Party concerned, such as those authorized to undertake investigations, where such a possibility exists;

(d) Is not incompatible with the provisions of this Convention; and

(e) The same matter is not being examined under another procedure of international investigation or settlement of the same nature; it shall request the State Party concerned to provide it with information on the situation of the persons sought, within a time limit set by the Committee.

3. In the light of the information provided by the State Party concerned in accordance with Paragraph 2 of this Article, the Committee may transmit recommendations to the State Party, including a request that the State Party should take all the necessary measures, including interim measures, to locate and protect the person concerned in accordance with this Convention and to inform the Committee, within a specified period of time, of measures taken, taking into account the urgency of the situation. The Committee shall inform the person submitting the urgent action request of its recommendations and of information provided to it by the State as it becomes available.

4. The Committee shall continue its efforts to work with the State Party concerned for as long as the fate of the person sought remains unresolved. The person presenting the request shall be kept informed.

The CED, by virtue of Art 30, is empowered to receive, as a matter of urgency, a request from relatives of the disappeared person or their legal representatives, their counsel or any person authorized by them or having legitimate interest, for finding and protecting a disappeared person. It is legally obligated to take cognizance of, and act upon, such a 'request for urgent action' unless the request: (i) is manifestly unfounded, (ii) constitutes an abuse of the right, (iii) is presented to competent authorities of the State, (iv) is incompatible with the Convention, or (v) is seized by any other international authority. The CED is authorized to seek the requisite 'information' from the State concerned about the alleged enforced disappearance. The State is bound to furnish, within the time stipulated by the CED, the solicited 'information'. The CED, in the light of the information received, is empowered to recom- 
mend 'necessary measures' (including interim measures) to be taken by the State concerned for locating and protecting the (disappeared) person. The State is under obligation to take, within the time stipulated by the CED, all the 'necessary measures' for locating and protecting the person and to inform the CED thereof. The CED, in turn, is required to keep informed the person seeking 'urgent action' of its recommendations sent to the State and the information received from it. The Convention mandates the CED to keep its efforts on, and to work with the State concerned until the fate of the person sought is resolved.

The 'urgent or emergency procedure' outlined in Art 30 of the Convention is indeed a very substantive innovative measure for locating and protecting a disappeared person. It is certainly going to prove itself a key provision for preventing enforced disappearance as it allows the CED to seek 'information' of a disappeared person and to 'recommend' measures to be taken by the State for his protection. It is needless to remind a well-informed student of international human rights law that the 'urgent procedure' does not have any parallels in the hitherto international human rights instruments. A person invoking the 'urgent measure' is not required to exhaust domestic remedies before he seeks help of the CED for locating and protecting a disappeared person.

However, it is pertinent to note that the delegation of Egypt (for itself and on behalf of the delegations of Iran, India, China and Angola), plausibly taking clue from the thitherto international human rights instruments, proposed that the exhaustion of domestic remedies should be added as an additional criterion for admissibility of the 'urgent action measures'. While other numerous delegations, led by Argentina, Switzerland and Italy, opposed the proposal on the ground that the main purpose of the 'urgent procedure' is to prevent 'enforced disappearance' and it, unlike the individual complaint procedure provided under other human rights instruments, is not of 'judicial' in nature. However, in final text of the article, exhaustion of domestic remedies was left out but an additional element that 'the same matter is not being examined under another procedure of international investigation or settlement of the same nature' was added. ${ }^{53}$

${ }^{53}$ See, UN Commission on Human Rights, Report of the Intersessional Open-ended Working Group to Elaborate a Draft Legally Binding Normative Instrument for the Protection of All Persons from Enforced Disappearance, UN Doc E/ CN.4/2004/59, 23 February 2004, para
153 and UN Commission on Human Rights, Intersessional Open-ended Working Group to Elaborate a Draft Legally Binding Normative Instrument for the Protection of All Persons from Enforced Disappearance, $5^{\text {th }}$ Session (Geneva, 1223 September 2005). 
Art 34, which carves out another innovative strategy to combat enforced disappearance, empowers the CED, when it receives a well-founded information about situations of 'widespread or systematic' practice of enforced disappearances in the territory under the jurisdiction of a State Party, to seek all relevant information from the State concerned on the situation and to urgently bring the matter to the attention of the UN General Assembly. Delving this strategy, Art 34 provides: ${ }^{54}$

If the Committee receives information which appears to it to contain wellfounded indications that enforced disappearance is being practiced on a widespread or systematic basis in the territory under the jurisdiction of a State Party, it may, after seeking from the State Party concerned all relevant information of the situation, urgently bring the matter to the attention of the General Assembly of the United Nations, through the Secretary-General of the United Nations.

Art 34, enabling the CED to bring widespread or systematic practice of enforced disappearance to the attention of the UN General Assembly, can be perceived as another innovative preventive measure designed under the 2007 Convention. It is novel as it, unlike in other international human rights instruments, deals with referral by the treaty monitoring body (CED) to the UN (the General Assembly). Significance and potentials of art 34 in combating enforced disappearance can be felt easily if one recalls textual and operational ambit of art 7 of the Rome Statute that also, in a different context, deals with 'widespread or systematic' enforced disappearance.

\section{Conclusion}

The 2007 Convention, a specific, binding and normative international instrument on enforced disappearance, not only makes 'enforced disappearance' a crime but also an element of a crime against humanity. With a view to combating 'enforced disappearance' and imposing liability on its perpetrator, the Convention imposes a set of obligations on the States Parties. For its effective implementation at the national level, it provides for a three-tier national jurisdictional system. It recognizes competence of the State where the offence of enforced disappearance is committed, the State of the alleged offender, and the State of the victim of the enforced disappearance to try the

54 This measure may further lead to bringing the issue (through the appropriate channels set forth in art 13 of the 1998 Rome Statute) to the ICC so that it may exercise its jurisdiction for the crime against humanity of enforced disappearance. See, United Nations, Economic and
Social Council, Report of the Intersessional Open-ended Working Group to Elaborate a Draft Legally Binding Normative Instrument for the Protection of All Persons from Enforced Disappearances, supra n 24, para 138. 
alleged perpetrator. For global monitoring of the Convention, it provides for the establishment of the CED. The CED is authorized: (i) to receive and examine the States Parties' Reports outlining the measures taken by them in discharging their obligations under the Convention, (ii) to receive and consider inter-State communications alleging that the other State Party is violating its obligations under the Convention, and (iii) to entertain individual petitions about acts of enforced disappearance.

In addition, the Convention provides for two innovative procedures for preventing the acts of enforced disappearance effectively. They are the 'emergency procedure' and the procedure to draw attention of the UN General Assembly to 'systematic practice of enforced disappearance' in a State Party.

The Convention also empowers the victims of enforced disappearance, as a matter of right, to seek reparation, prompt and fair compensation, and to know the truth about whereabouts of the disappeared person. It obligates the States Parties to take preventive measures, by increasing safeguards in connection with detention, and in particular by imposing an absolute ban on secret detention.

However, the Convention, as discussed earlier, has some structural and operational inbuilt weaknesses. Contrary to its Preambulary assertion, the Convention does not treat every act of enforced disappearance as a crime against humanity. Only a 'widespread or systematic practice' of enforced disappearance amounts to a crime against humanity. It also excludes from its ambit an act of enforced disappearance perpetrated by non-State actors. Further, the so called 'constructive ambiguity' left in the definitional clause leaves scope for, and choice of, the criminalization of 'enforced disappearance' in national criminal laws of the States Parties and in the consequential liability therefor. Some of the monitoring and implementation strategies, as mentioned earlier, are bridled with some inbuilt weaknesses that affect their efficacy.

In spite of these deficiencies and a cluster of legal issues pertaining to some of its provisions, the Convention is one of the most ambitious and strongest human rights treaties ever adopted by the United Nations. It aims to prevent enforced disappearances, establish the truth when it occurs, and punish its perpetrators. It also provides for reparations of the victims of enforced disappearance and their families. It recognizes the new human right of a person not to be subjected to enforced disappearance and guarantees him and his relatives and legal representatives the right to know the truth. It precludes a State Party from justifying enforced disappearance in any circumstance whatsoever, even a state of war or war against terror. 
Peculiar structural and operational framework of the 2007 Convention will undoubtedly make the Convention a useful tool in the ongoing struggle against enforced disappearance and in upholding human dignity and humanity of involuntarily disappeared persons, provided it receives the universal acceptance. $^{55}$

\footnotetext{
${ }^{55}$ It requires ratification by 20 States to enter it into force. [vide Art 39].
} 